RESEARCH PAPER

J. Food Sci. Technol. Nepal, Vol. 8 ( 75-77 ) 2013

ISSN: 1816-0727

\title{
Utilisation of Lemon Juice in the Preparation of Tofu from Black Soyabean
}

\author{
GHANENDRA GARTAULA ${ }^{1,2^{*}}$, SANTOSH POKHAREL ${ }^{2}$ and GANESH DAWADI ${ }^{3}$ \\ ${ }^{1}$ Department of Food Technology, GoldenGate International College, Tribhuvan University, Nepal \\ ${ }^{2}$ Padmashree International College, Tribhuvan University, Nepal \\ ${ }^{3}$ Department of Food Technology and Quality Control, Ministry of Agriculture Development, Nepal
}

*Corresponding author: g.gartaula@goldengate.edu.np

The present study was undertaken to study the effect of lemon juice on the quality of tofu prepared from black soyabean. Soymilk tofu coagulated with three different coagulants viz. calcium chloride, calcium sulphate and lemon juice were compared in terms of yield and sensory attributes. The yield percentage and overall acceptability of lemon juice tofu was significantly higher than calcium chloride tofu but no significant change was observed with calcium sulphate tofu. The crude protein, crude fat, crude fiber and ash content of the lemon juice tofu was found to be $51.58 \%, 13.45 \%, 6.88 \%$ and $3.15 \%$ in dry basis, respectively.

Keywords: Coagulants, lemon juice, sensory quality, tofu, black soyabean

\section{Introduction}

Tofu, also known as soyabean ( or soybean) curd, is made by coagulation of heated soya milk with a coagulant, followed by moulding and pressing the curd to draw the whey. Yield, quality and texture of tofu are influenced by several factors such as variety of soyabeans and storage conditions, time and temperature of soaking the soybeans, extent of heat-treatment of soymilk, type and concentration of coagulant and rate of stirring and coagulation temperature (Cai et al., 1997; Karim et al., 1999; Noh et al., 2005; Obatolu, 2008; Prabhakaran et al., 2006; Shih et al., 2002; Sun and Breene, 1991). Various coagulants have been used in the preparation of tofu, each coagulant resulting in a product with textural characteristics. Calcium sulfate, calcium chloride, magnesium sulfate and magnesium chloride are many of the different types of coagulants used on an industrial scale for the preparation of tofu. Coagulation occurs due to the cross-linking of protein molecules in soymilk with the divalent cations (Saio et al., 1967; Lim et al., 1990).

Among a variety of soyabeans, the black soyabean is reported to have discriminating components, such as phenolic acids, anthocyanins and isoflavones $(\mathrm{Xu}$ and Chang, 2008) and is also known to display superior biological activities to yellow and green soyabeans, such as free radical scavenging activitiesand inhibition of LDL oxidation (Astadi et al., 2009; Takahashi et al., 2005; Xu and Chang, 2008). In addition, anti-inflammatory (Kim et al., 2008) and anticancer (Hung et al., 2007) activities of black soyabean have also been reported. A study has been done on black soyabean touhua using glucono- $\delta$ - lactone (Chang et al., 2009). However, study on black soyabean tofu has not been found yet. On the other hand, lemon juice as a coagulant could serve as the cheap source as compared to expensive salts. Further, lemon is readily available in the local market in all seasons which could help small-scale processors in tofu preparation. Hence, an attempt was made to study the use of lemon juice as a coagulant in the preparation of tofu from black soyabean and compare its yield with commercial coagulants.

\section{Materials and Methods \\ Materials}

Common black variety of soyabean (Glycine max) locally known as 'sathiya' was collected from the Everest Seed Industries, Khumaltar, Lalitpur, Nepal. The coagulants calcium chloride and calcium sulphate dehydrate were of Fisher Scientific Inc., India while lemon was obtained from the local market.

\section{Preparation of tofu}

400 gm of black soyabean was taken separately for each of the three coagulating agents and were soaked separately in water (six times bean weight) for $12 \mathrm{~h}$ at ambient temperature $\left(24 \pm 2^{\circ} \mathrm{C}\right)$. The swelled beans were dehulled manually and grinding was done with intermittent addition of potable water. The raw bean to water ratio was maintained at $1: 10$ by adding water. The mash was heated and boiled for 10 minutes and filtered through muslin cloth.The temperature of milk was lowered to $75{ }^{\circ} \mathrm{C}$. Then the coagulating agents were added with continuous stirring. The concentration of the salts used was $0.3 \%$ and the titratable acidity of lemon juice was 
The proximate composition of LJ-tofu is given in Table 3. The tofu preparation from black soyabean by using lemon as a coagulating agent contained $71.88 \%$ moisture content (dry basis). The contents of protein, fat, crude fiber and ash were $51.58 \%, 13.45 \%, 6.88 \%$ and 3.15 $\%$ respectively on dry basis. The protein content was at par with the tofu prepared from T3 black soyabean (Shih et al., 2002). However, the crude fat and ash content were found to be lower in LJ-tofu. The results were not found to comply with that of Obatolu (2008) too. This might be due to difference in variety of soyabean, type of coagulant and the amount of coagulant used (Cai et al., 1997; Karim et al., 1999; Obatolu, 2008; Prabhakaran et al., 2006; Shih et al., 2002; Sun and Breene, 1991).

\section{Conclusions}

It has been confirmed the feasibility of replacing commercial salts by lemon juice for the coagulation of soyabean milk in the manufacture of tofu from black soyabean. The yield of tofu was also higher and sensory properties were also better.

\section{References}

Astadi I.R., Astuti M., Santoso U and Nugraheni P.S. (2009).In vitro antioxidant activity of anthocyanins of black soybean seed coat in human low density lipoprotein (LDL). Food Chem., 112: 659-663

Cai T.D., Chang K.C., Shih M.C., Hou H.J. and Ji M. (1997). Comparison of bench and production scale methods for making soymilk and tofu from 13 soybean varieties. Food Res. Int., 30(9): 659-668

Chang Y., Su H. and Shiau S. (2009). Rheological and textural characteristics of black soybean touhua (soft soybean curd) prepared with glucono-d-lactone. Food Chem., 115: 585-591

Hou H.J, Chang K.C. and Shih M.C. (1997). Yield and textural properties of soft tofu as affected by coagulation method. J. Food Sci., 62(4): 824-827

Hou H.J. and Chang K.C. (2003). Yield and textural properties of tofu as affected by the changes of phytate content during soyabean storage. J. Food Sci., 68(4): 1185-1191

Hung Y.H., Huang H.Y. and Chou C.C. (2007). Mutagenic and antimutagenic effects of methanol extracts of unfermented and fermented black soybeans. Int. J. Food Microbiol., 118: 62-68.

Karim A.A., Sulebele G.A., Azhar M.E. and Ping C.Y. (1999). Effect of carrageenan on yield and properties of tofu. Food Chem., 66: 159-165

Kim J.M., Kim J.S., Yoo H., Choung M.G. and Sung M.K. (2008). Effects of black soybean [Glycine max (L.)Merr.] seed coats and its anthocyanidins on colonic inflammation and cell proliferation in vitro and in vivo. J. Agric. Food Chem., 56: 842733.

Lim B. T., de Man J. M., de Man L. and Buzzel R. I. (1990). Yield and quality of tofu as affected by soybeans and soymilk characteristics: Calcium sulphate coagulant. J. Food Sci., 55: 1088-1092

Noh E.J., Park S.Y., Pak J.I., Hong S.T. and Yun S.E. (2005). Coagulation of soymilk and quality of tofu as affected by freeze treatment of soybeans. Food Chem., 91: 715- 721

Obatolu V.A. (2008). Effect of different coagulants on yield and quality of tofu from soymilk. Eur. Food Res. Technol., 226: 467-472.

Prabhakaran M.P., Perera C.O. and Valiyaveettil S. (2006). Effect of different coagulants on the isoflavone levels and physical properties of prepared firm tofu. Food Chem., 99: 492-499

Ranganna S. (2008). Handbook of Analysis and Quality control for Fruit and Vegetable $\quad \mathrm{p} \mathrm{r} \mathrm{o} \mathrm{d} \mathrm{u} \mathrm{c} \mathrm{t} \mathrm{s}$ $\left(2^{\text {nd }} \boldsymbol{e d}\right)$. Tata McGraw Hill, New Delhi.

Saio K., Koyama E. and Watanabe T. (1967). Proteincalcium-phytic acid relationships in soybean.Part I. Effect of calcium and phosphorus on the solubility characteristics of soybean meal protein. Agric. Biol. Chem., 31: 1195-1200.

Shih M.C., Yang K.T. and Kuo S.J. (2002). Quality and antioxidative activity of black soybean tofu as affected by bean cultivar. J. Food Sci., 67(2): 480484

Sun N. and Breene W. M. (1991). Calcium sulphate concentration influence on yield and quality of tofu from five soybean varieties. J. Food Sci., 56(6): 1604-1607.

Takahashi R., Ohmori R., Kiyose C., Momiyama Y., Ohsuzu F. and Kondo K. (2005). Antioxidant activities of black and yellow soybeans against low density lipoprotein oxidation. J. Agric. Food Chem., 53: 4578-82.

$\mathrm{Xu}$ B. and Chang S.K.(2008). Total phenolics, phenolic acids, isoflavones, and anthocyanins and antioxidant properties of yellow and black soybeans as affected by thermal processing. J. Agric. Food Chem., 56:7165-75. 